\title{
Factors Affecting the Internet Game Addiction Risk of Elementary School Students in Multicultural Families
}

\author{
On Choi ${ }^{1}$, Keum Seong Jang ${ }^{2}$, Nam Young Kim ${ }^{3}$ \\ ${ }^{1}$ Doctoral Student, Department of Nursing, Graduate school, Chonnam National University, Gwangju; ${ }^{2}$ Professor, College of Nursing, the Research \\ Institute of Nursing Science, Chonnam National University, Gwangju; ${ }^{3}$ Professor, Department of Nursing, Honam University, Gwangju, Korea
}

Objectives: This study aims to determine that the general characteristics, self-esteem, parent-child relationships, and school life adjustment differ between the Internet game addiction risk group and the non-addiction group, and identify the factors affecting the risk of Internet game addiction. Methods: Data were collected from 24 January to 17 April 2013. A total of 209 subjects were analyzed in the 4th, 5th, 6th grade of elementary school students of multicultural families in Gwangju and Jeollanam-do Province, South Korea. Results: There was a statistically significant difference in selfesteem, parent-child relationship, and school life adjustment between the Internet game addiction risk group and the non-addiction group. The factors affecting Internet game addiction risk to elementary school students in multicultural families were gender, foreign mother's country, school life adjustment in order. Conclusions: It is necessary to consider cultural sensitivity in developing Internet game addiction risk prevention program, and to grasp the Internet game addiction targeting multicultural elementary school students.

Key words: Internet game, Addiction, Self-esteem, Parent-child relationship, School life adjustment

\section{INTRODUCTION}

With the activation of international exchanges, South Korea is in the transition period from a homogeneous country to a multiracial and multicultural one. As the tertiary industry became a primary industry in the 1990s, South Korea saw local manufacturing and production manpower decrease and accepted foreign workers to solve this problem. In the 2000s, social avoidance of marriage with men in the primary industry led to a drastic increase in the number of international marriages [1]. According to the statistical report made by Ministry of Gender Equality and Family in 2015, the number of Married immigrants, naturalized person in South Korea is estimated at 304,516, which increased $7.52 \%$ compared to in 2012. However, multicultural families in South Korea have lots of problems to solve due to different cultures and living habits compared with general families. Such problems can affect children in

Corresponding author: Nam Young Kim

120 Honamdae-gil, Gwangsan-gu, Gwangju 62399, Korea

E-mail: aqua29@paran.com

Received: January 5, 2019 Revised: February 22, 2019 Accepted: February 25, 2019

No potential conflict of interest relevant to this article was reported. multicultural families [2]

South Koreans who have formed multicultural families are faced with social and cultural prejudices and discrimination because most of them are in the economically underprivileged bracket and reside in industrial complexes or in agricultural or fishing villages [3]. Compared with children, those in multicultural families may have difficulties due to different cultural and historical backgrounds, communication problems, their parents' socio-economically low status, and differences in language, culture, and education type; they may also experience confused identity, difficulties in school adjustment, and emotional distress [4].

In particular, South Korea established an information-oriented society due to structural change, as well as cultural one, and its entrance into a multicultural society in the 2000s. In the midst of such a social atmosphere, Korea entered the information society uniquely in the world. Due to rapid changes in the information society, social problems have

How to cite this article:

Choi 0, Jang KS, Kim NY. Factors affecting the internet game addiction risk of elementary school students in multicultural families. J Health Info Stat 2019;44(1):64-72. Doi: https://doi.org/10.21032/ jhis.2019.44.1.64

(C) It is identical to the Creative Commons Attribution Non-Commercial License (http://creativecommons.org/licenses/by-nc/4.0) whichpermit sunrestricted non-commercial use, distribution, and reproduction in any medium, provided the original work is properly cited.

(c) 2019 Journal of Health Informatics and Statistics 
arisen. Among them, the problems related to Internet addiction of young people in growing age are seriously reported. As in 2016, the Internet addiction rate for teenagers is one in every seven, and multicultural families are more likely to be exposed to Internet addiction [5].

According to research on the Internet addiction status for adolescents, as released by a South Korean government agency in 2012, adolescents in multicultural families (12.3\%) were more likely to become addicted to Internet than adolescents in general (10.7\%) while elementary school children (30.1\%) were more likely to become addicted to Internet than middle school students (25\%). In particular, Internet-related problems for elementary school children in the transition period from childhood to adolescence can cause social maladjustment, which involves anxiety, frustration, and fear, as well as problem behaviors [6] and become chronic, unless treated properly, which may lead to juvenile delinquency [7]. It is therefore necessary to conduct research on the possibility of Internet games addiction among elementary school children who start to use Internet; in particular, it is necessary to investigate the risk of Internet game addiction among children in multicultural families with the objective of preventing and managing Internet game addiction.

Most of the domestic studies on Internet game addiction for elementary school children addressed variables related to Internet addiction, instead of applying an approach based on comprehensive factors describing Internet game addiction [7-9].

According to previous studies, the factors affecting Internet game addiction can be divided into personal, environmental, and social aspects. Gender, self-esteem, difficulty in self-regulation, and psychological instability were found to be more vulnerable to Internet addiction [10,11]. The effect of the Internet game addiction was influenced by parents' parenting style, attachment relationship, and communication level [12]. And, adaptation to school life as aspect of social factors is also one of the influencing factors of Internet game addiction. The higher the stress in friendship and teacher-students relationship and the lower the adaptability to school life, the higher the degree of Internet game addiction $[10,13]$.

It has been reported that Internet game addiction in adolescence is affected by self-esteem, self-control, antagonistic parenting attitude, overprotective parent attachment, and closed parent communication [14], which lower levels of self-confidence, lead to difficulty in self-regulation, and result to psychological instability, making them more vulnerable to Internet addiction $[15,16]$.

Meanwhile, research has been conducted on Korean culture adjust- ment and school life adjustment for children in multicultural families [3] and little research has been conducted on Internet or game addiction for children in multicultural families. In addition to the research on maladjustment to the South Korean society for children in multicultural families, this study is conducted as follows as the social issues, such as Internet game addiction, are expected to affect the growth and development of the children in the socially underprivileged members.

This study aims to determine if the general characteristics, self-esteem, parent-child relationships, and school life adjustment differ between the Internet game addiction risk and the non-addiction group, and identify factors affecting Internet game addiction risk in elementary school students of multicultural families.

The research questions are as follows;

1) What is the differences in the general characteristics of risk and non-addiction group in Internet game addiction of elementary school students in multicultural families?

2) What about self-esteem, parent-child relationship, and school life adjustment between risk and non-addiction group in Internet game addiction of elementary school students in multicultural families?

3) What are the factors that affect the risk of Internet game addiction among elementary school students in multicultural families?

\section{METHODS}

\section{Setting and sample}

The subjects in this study was composed of elementary school students in multicultural families in Gwangju and Jeollanam-do Province. The population was limited to students in grades 4,5 , and 6 of multicultural families. The reason is that they correctly understood the questionnaires and the upper grades of elementary school were appropriate as focus groups of research in Internet game addiction. The sample size is calculated using the $\mathrm{G}^{\star}$ Power 3.1.9.2 program. In the case of logistic regression analysis by using odds ratio (OR); 1.5, significance level; 5\%, power (1- $\beta$ ); 80\%, the calculated number of sample size was 208 [17].

Based on this, we took a total of 300 questionnaires in consideration of recovery rate and omission of responses. A total of 213 questionnaires (71\%) were returned; of these, a total of 209 copies were finally analyzed, with the exception of two containing unreliable answers and two in the Internet game addiction group. 


\section{Measures and instruments}

Rosenberg's [18] self-esteem scale with 10 items was used. The total score ranges from 10 to 50 , with a higher score meaning a more positive awareness of oneself and higher self-esteem. The Cronbach's a was 0.85 at the time of development of the tool and 0.96 in this study.

The Korean version of the parent-child relationship scale manufactured by Choi [19] was used. This scale has a total of 40 items: 20 with the same contents about father-child and mother-child relationships. The total score ranges from 40 to 200 . The Cronbach's a was 0.95 at the time of development of the tool and 0.95 in this study.

Woo's [20] adaptation of the elementary school life adjustment scale developed by Yim [21] was used. It is composed of four sub-areas: teacher-student relationships, peer relationships, school classes, and school rules and contains a total of 32 items, 8 for each area. The total score ranges from 32 to 160. The Cronbach's a was 0.80 in Woo [20] and 0.91 in this study.

Young's [22] internet addiction test modified to have a total of 20 items in a five-point scale by Jung [23] was used. The total score ranges from 20 to 100: 20-39 for the non-addiction group, 40-69 for the group at risk of addiction, and 70-100 for the addicted group. The Cronbach's a was 0.93 in Jung [23] and 0.91 in this study.

\section{Data collection and procedure}

Before conducting this study, preliminary research was conducted in 20 elementary school boys and 20 girls in December 2012 to determine if the questionnaire met the subjects' level. The complemented self-administered questionnaires were approved by the IRB and started to be distributed on January 24, 2013 and returned by April 17, 2013.

The researcher explained the goal and methods of this study to teachers at schools and got their consent through personal visit, e-mail, or phone. The teachers were asked to give a written explanation of the subjects' rights, the study's confidentiality, and the goal of the study, and a consent form to students and parents in multicultural families; then, questionnaires were distributed to those spontaneously giving written consent to participation in the study. The completed questionnaires were either personally collected or returned by the researcher or by teachers in charge of students in multicultural families (or relevant ones) by mail.

\section{Data analysis}

The data were analyzed using IBM SPSS 21.0 (IBM Co., Armonk, NY,
USA) program. The general characteristics and the degree of self-esteem, parent-child relationship, and school life adjustment between the Internet game addiction risk and the non-addiction groups were analyzed using descriptive statistics. The differences in the general characteristics, self-esteem, parent-child relationship, and school life adjustment between the two groups were analyzed by using t-test, $\chi^{2}$-test, and Fisher's exact test. Binary logistic regression analysis was performed to identify the factors affecting Internet game addiction risk for elementary school students in multicultural families.

\section{Ethical considerations}

Ethical approval (IRB No. CNUH-2013-010) was provided by the Institutional Review Board from Chonnam National University Hospital. Approval from the relevant institution directors where data collection took place was also obtained. Finally, all participants and their parents provided written informed consent before completing the questionnaires.

\section{RESULTS}

\section{The differences in general characteristics between the two groups}

Boys formed $69.4 \%$ in the group at risk of addiction and $40.1 \%$ in the non-addiction group. Fifth-graders formed $43.1 \%$, fourth-graders $36.1 \%$, and sixth-graders $20.8 \%$ in the group at risk of addiction, while each of fourth- and fifth-graders formed $40.9 \%$ and sixth-graders $18.2 \%$ in the non-addiction group.

As for difficulty in school life, $75.7 \%$ in the group at risk of addiction and $85.3 \%$ in the non-addiction group had 'no specific difficulty' $86.2 \%$ of the group at risk of addiction used Internet games and 6.9\% used no Internet game or had used to them, whereas $59.9 \%$ of the non-addiction group used Internet games, 25.5\% used no Internet game, and 14.6\% had used to them.

The foreign parents in the group at risk of addiction and those in the non-addiction group scored an average of $9.34( \pm 2.06)$ and $10.17( \pm 1.75)$ for Korean ability involving speaking, writing, and reading. The level of Korean language was ‘high' for $41.4 \%$ of the group at risk of addiction and $56.0 \%$ of the non-addiction group. The parents of the group at risk of addiction scored higher for every area of Korean ability than those of the non-addiction group. 
Table 1. The differences in general characteristics between the two groups $(n=209)$

\begin{tabular}{|c|c|c|c|c|}
\hline \multirow[b]{2}{*}{ Characteristics } & $N A(n=137)$ & IAR $(n=72)$ & \multirow{2}{*}{$\chi^{2}$ or $t^{2}$} & \multirow[b]{2}{*}{$p$} \\
\hline & $\begin{array}{c}\mathrm{n}(\%) \text { or } \\
\text { Mean } \pm \text { SD }\end{array}$ & $\begin{array}{c}n(\%) \text { or } \\
\text { Mean } \pm \text { SD }\end{array}$ & & \\
\hline Gender & & & 16.21 & $<0.001$ \\
\hline Male & $55(40.1)$ & $50(69.4)$ & & \\
\hline Female & $82(59.9)$ & $22(30.6)$ & & \\
\hline Grade & & & 0.49 & 0.782 \\
\hline 4th & $56(40.9)$ & $26(36.1)$ & & \\
\hline 5th & $56(40.9)$ & $31(43.1)$ & & \\
\hline 6 th & $25(18.2)$ & $15(20.8)$ & & \\
\hline \multicolumn{5}{|l|}{ Difficulties of school life ${ }^{1}$} \\
\hline Rare difficulties & $122(85.3)$ & $57(75.7)$ & - & - \\
\hline To tease about poor grade & $3(2.1)$ & $4(5.2)$ & & \\
\hline To tease about appearance & $5(3.5)$ & $2(2.5)$ & & \\
\hline To have no friend & $2(1.4)$ & $1(1.3)$ & & \\
\hline To exclude activities & $2(1.4)$ & $2(2.5)$ & & \\
\hline To bully and beat & $1(0.7)$ & $6(7.8)$ & & \\
\hline Not to believe & $5(3.5)$ & $2(2.5)$ & & \\
\hline $\begin{array}{l}\text { To tease about speaking } \\
\text { Korean poorly }\end{array}$ & $3(2.1)$ & $2(2.5)$ & & \\
\hline Internet game utility & & & 15.57 & $<0.001$ \\
\hline Yes & $82(59.9)$ & $62(86.2)$ & & \\
\hline No & $35(25.5)$ & $5(6.9)$ & & \\
\hline Used to & $20(14.6)$ & $5(6.9)$ & & \\
\hline Foreign parents & & & - & 0.558 \\
\hline Father & $4(2.9)$ & $1(1.4)$ & & \\
\hline Mother & $127(92.7)$ & $70(97.2)$ & & \\
\hline Both & $6(4.4)$ & $1(1.4)$ & & \\
\hline \multicolumn{5}{|l|}{ Continental classification } \\
\hline Father's nationality & & & - & $>0.999$ \\
\hline East-South Asia & $2(22.2)$ & $1(50.0)$ & & \\
\hline East-North Asia/Others & $7(77.8)$ & $1(50.0)$ & & \\
\hline Mother's nationality & & & 9.75 & 0.002 \\
\hline East-South Asia & $58(43.3)$ & $48(66.7)$ & & \\
\hline East-North Asia/Others & $76(56.7)$ & $24(33.3)$ & & \\
\hline $\begin{array}{l}\text { Foreign parents' Korean } \\
\text { ability }\end{array}$ & $10.17 \pm 1.75$ & $9.34 \pm 2.06$ & 3.35 & 0.001 \\
\hline Speaking & $3.52 \pm 0.53$ & $3.34 \pm 0.66$ & & \\
\hline Writing & $3.25 \pm 0.63$ & $2.91 \pm 0.72$ & & \\
\hline Reading & $3.40 \pm 0.59$ & $3.09 \pm 0.68$ & & \\
\hline $\begin{array}{l}\text { Foreign parents' level of } \\
\text { Korean language }\end{array}$ & & & 8.97 & 0.011 \\
\hline Low & $1(0.7)$ & $5(7.1)$ & & \\
\hline Moderate & $58(43.3)$ & $36(51.4)$ & & \\
\hline High & $75(56.0)$ & $29(41.4)$ & & \\
\hline
\end{tabular}

NA, non-addiction; IAR, Internet game addiction risk; SD, standard deviation.

${ }^{1}$ Multiple responses.

${ }^{2}$ Fisher's exact test.
As for the general characteristics in the group at risk of addiction and the non-addiction group, the risk of Internet game addiction was significantly associated statistically with gender $\left(\chi^{2}=16.21, p<0.001\right)$, Internet game utility $\left(\chi^{2}=15.57, p<0.001\right)$, continental classification by foreign mother's nationality $\left(\chi^{2}=9.75, p=0.002\right)$, and foreign parents' Korean ability $(\mathrm{t}=3.35, p=0.001)$ and foreign parents' level of Korean language $(\mathrm{t}=8.97, p=0.011)($ Table 1$)$.

\section{The differences in self-esteem, parent-child relationships,}

\section{and school life adjustment between the two groups}

The group at risk of Internet game addiction and the non-addiction group scored an average of $33.43( \pm 5.35)$ and $36.95( \pm 7.33)$, respectively, out of 50 for self-esteem. The non-addiction group scored significantly higher on average for self-esteem and there were statistically significant inter-group differences in self-esteem $(\mathrm{t}=3.96, p<0.001)$ (Table 2).

The group at risk of Internet game addiction and the non-addiction group scored $139.99( \pm 26.85)$ and $157.17( \pm 25.63)$, respectively, for parent-child relationships. The non-addiction group scored significantly higher on average for parent-child relationships and there were statistically significant inter-group differences in parent-child relationships $(\mathrm{t}=4.53, p<0.001)($ Table 2$)$.

The group at risk of Internet game addiction and the non-addiction group scored an average of $103.44( \pm 14.21)$ and $114.88( \pm 17.99)$, respectively, for school life adjustment. The non-addiction group scored signifi-

Table 2. The differences in self-esteem, parent-child relationships, and school life adjustment between the two groups $(n=209)$

\begin{tabular}{|c|c|c|c|c|}
\hline \multirow{2}{*}{ Variables } & \multirow{2}{*}{$\begin{array}{c}\mathrm{NA}(\mathrm{n}=137) \\
\text { Mean } \pm \text { SD }\end{array}$} & \multirow{2}{*}{$\begin{array}{l}\text { IAR }(n=72) \\
\text { Mean } \pm S D\end{array}$} & \multirow{2}{*}{$\mathrm{t}$} & \multirow{2}{*}{$p$} \\
\hline & & & & \\
\hline Self-esteem & $36.95 \pm 7.33$ & $33.43 \pm 5.35$ & 3.96 & $<0.001$ \\
\hline $\begin{array}{l}\text { Parents-children } \\
\text { relationship }\end{array}$ & $157.17 \pm 25.63$ & $139.99 \pm 26.85$ & 4.53 & $<0.001$ \\
\hline Friendly & $55.39 \pm 11.43$ & $47.73 \pm 11.50$ & 4.48 & $<0.001$ \\
\hline Devoted & $47.26 \pm 8.00$ & $42.44 \pm 7.26$ & 3.77 & $<0.001$ \\
\hline Respectful & $31.43 \pm 6.30$ & $28.28 \pm 4.87$ & 3.56 & $<0.001$ \\
\hline Strict & $23.09 \pm 6.41$ & $20.97 \pm 3.22$ & 2.79 & 0.060 \\
\hline School life adjustment & $114.88 \pm 17.99$ & $103.44 \pm 14.21$ & 5.03 & $<0.001$ \\
\hline $\begin{array}{l}\text { Teacher-student } \\
\text { relationships }\end{array}$ & $28.96 \pm 4.28$ & $26.12 \pm 3.85$ & 4.37 & $<0.001$ \\
\hline Peer relationships & $30.05 \pm 4.90$ & $26.45 \pm 3.79$ & 4.23 & $<0.001$ \\
\hline School classes & $28.17 \pm 5.23$ & $25.58 \pm 3.85$ & 3.59 & $<0.001$ \\
\hline School rules & $27.70 \pm 3.58$ & $25.29 \pm 2.72$ & 4.55 & $<0.001$ \\
\hline
\end{tabular}

NA, non-addiction; IAR, Internet game addiction risk; SD, standard deviation. 
Table 3. Univariate regression for variables $(n=209)$

\begin{tabular}{|c|c|c|c|c|}
\hline \multirow{2}{*}{ Variables } & \multirow{2}{*}{ B } & \multicolumn{2}{|c|}{ Adjusted for all variables } & \multirow{2}{*}{$p$} \\
\hline & & OR & $95 \% \mathrm{Cl}$ & \\
\hline \multicolumn{5}{|l|}{ Gender } \\
\hline Male & & 1.00 & & \\
\hline Female & -1.32 & 0.27 & $1.85-6.22$ & $<0.001$ \\
\hline FP' Korean ability & 2.17 & 8.73 & $0.63-0.90$ & 0.015 \\
\hline \multicolumn{5}{|l|}{ FP' level of Korean language } \\
\hline Very good & & 1.00 & & \\
\hline Good & 0.47 & 1.61 & $0.88-2.92$ & 0.120 \\
\hline Poor & 2.56 & 12.93 & $1.45-111.47$ & 0.022 \\
\hline \multicolumn{5}{|c|}{ Continental classification in FMN } \\
\hline East-South Asia & & 1.00 & & \\
\hline East-North Asia/Others & -1.15 & 0.32 & $1.40-4.67$ & $<0.001$ \\
\hline Self-esteem & -0.08 & 0.93 & $0.88-0.97$ & 0.001 \\
\hline Parents-children relationship & -0.02 & 0.98 & $0.96-0.99$ & $<0.001$ \\
\hline School life adjustment & -0.42 & 0.96 & $0.94-0.98$ & $<0.001$ \\
\hline
\end{tabular}

$\mathrm{OR}$, odds ratio; $\mathrm{Cl}$, cinfidence interval; $\mathrm{FM}$, foreign mother's nationality; $\mathrm{FP}$, foreign parents.

cantly higher on average for school life adjustment and there were statistically significant inter-group differences in school life adjustment $(\mathrm{t}=$ $5.03, p<0.001)$ (Table 2).

\section{Factors affecting risk of Internet game addiction}

To identify the primary factors affecting Internet game addiction risk for elementary school children in multicultural families, univariate analysis of gender, foreign mother's country of origin, foreign parents' level of Korean language and self-esteem, parent-child relationships, and school life adjustment, which were the characteristics significantly associated statistically with the Internet game addiction risk, was performed in the Internet game addiction risk group and the non-addiction group (Table 3). At this time, the categorical covariance was treated as the categorical variable of gender, Continental classification in foreign mother's nationality, foreign parents' level of Korean, except for foreign parents' Korean language ability, self-esteem, parent-children relationship, school life adjustment. Then, binary logistic regression analysis of the variables with significant results was performed (Table 4). The factors affecting the Internet game addiction risk for elementary school students in multicultural families were gender, continental classification in foreign mother's nationality, and school life adjustment in order. Of these, gender had the highest odds ratio: boys were 3.17 times at higher risk of Internet game addiction than girls $(\mathrm{OR}=3.17,95 \%$ confidence interval, 95\% CI: 1.646.14). Foreign mothers from East-South Asia led to 2.25 times higher risk
Table 4. Factors affecting risk of Internet game addiction ( $n=209)$

\begin{tabular}{|c|c|c|c|c|}
\hline \multirow{2}{*}{ Variables } & \multirow{2}{*}{ B } & \multicolumn{2}{|c|}{ Adjusted for all variables } & \multirow{2}{*}{$p$} \\
\hline & & OR & $95 \% \mathrm{Cl}$ & \\
\hline \multicolumn{5}{|l|}{ Gender } \\
\hline Male & 1.16 & 3.17 & $1.64-6.14$ & 0.001 \\
\hline Female & & 1.00 & & \\
\hline \multicolumn{5}{|c|}{$\begin{array}{l}\text { Continental classification } \\
\text { (Foreign mother's nationality) }\end{array}$} \\
\hline East-South Asia & 0.81 & 2.25 & $1.17-4.34$ & 0.016 \\
\hline East-North Asia/Others & & 1.00 & & \\
\hline School life adjustment & -0.04 & 0.96 & $0.94-0.98$ & $<0.001$ \\
\hline
\end{tabular}

$\mathrm{OR}$, odds ratio; $\mathrm{Cl}$, cinfidence interval.

Odds ratio were calculated using a binary logistic regression analysis and all variables were entered in step 1 .

Adjusted for gender, Continental classification (foreign mother's nationality), foreign parents' Korean ability, foreign parents' level of Korean language, self-esteem, parents-children relationship and school life adjustment.

Subjects with non-addiction group constituted the referent group.

of Internet game addiction than those from East-North Asia and other countries $(\mathrm{OR}=2.25,95 \% \mathrm{CI}: 1.17-4.34)$ and the group at risk of Internet game addiction scored 0.96 times lower for school life adjustment than the non-addiction group $(\mathrm{OR}=0.96,95 \% \mathrm{CI}$ : 0.94-0.98). The HosmerLemeshow test was conducted to determine the suitability of the model test so that the model appeared to be suitable result.

\section{DISCUSSION}

The subjects in this study were divided using Young's [22] internet addiction classification into the group at risk of Internet game addiction (34.4\%) and the non-addiction group (65.6\%). This result about the group at risk of Internet game addiction is slightly lower than the other study in elementary school children: the group at risk of Internet game addiction $(45.5 \%)$ [24].

Although foreign parents' Korean ability and level of Korean language was not a primary factor affecting the risk of Internet game addiction, a univariate analysis found that the foreign parents in the group without Internet game addiction had $\geq 12$ times higher Korean ability than those in the group at risk of addiction. On the basis of the finding [25] that a higher level of Korean ability might lead to better family communication, quicker adaptation to Korean culture, and better adaptation to the stream of child education, foreign parents' Korean ability may affect the risk of Internet game addiction for children in multicultural families. 
As a personal factor for the risk of Internet game addiction, self-esteem was significantly lower in the group at risk of Internet game addiction. This result was consistent with the finding that lower levels of satisfaction with oneself and the tendency to disregard oneself can increase the risk of Internet game addiction for children in multicultural families as well [6].

To determine the parent relationship as an environmental factor, this study used the Korean version of the parent-child relationship scale appropriate for the Korean society attaching greater importance to relationships than to individuals, whereas other researchers have used the Western parent relationship scale [19]. This is to determine parent-child relationships in the group at risk of Internet game addiction and the non-addiction group for elementary school children in multicultural families and identify the causal factors for the risk of Internet game addiction in consideration of the possible problems in understanding and adapting to Korean culture within multicultural families. The non-addiction group scored higher for a total of four sub-areas of parent-child relationships - friendly, devoted, respectful, and strict - than the group at risk of addiction. This result was consistent with the finding [14] that friendly, devoted, or properly controlled parent-child relationships might decrease the risk of Internet game addiction.

As a social factor for the risk of Internet game addiction, the group at risk of Internet game addiction scored lower on average for all the subareas of school life adjustment than the non-addiction group. The intergroup difference was greatest in the score for peer relationships than the other sub-factors: teacher-student relationships, school classes, and school rules. Students may discover themselves while making friends at school [26]. However, verbal and indirect aggression involving insulting remarks or teasing can interfere with these relationships while children failing to get along with others fail to find their own rights and become more depressed [20]. These negative results may affect their character formation and social development and make them vulnerable to Internet game addiction $[22,27]$. To put these results together, on the basis of the finding that parents with greater attention might induce their children to have higher levels of social competence and school life adjustment [28], children in multicultural families can be better at school life adjustment if they have parents with good information and adaptation to life in South Korea.

Discussion can be made on the basis of the main results, with the factors affecting the risk of Internet game addiction. First, gender was the factor most significantly affecting the risk of Internet game addiction: boys were approximately 3.2 times at higher risk of Internet game addiction than girls. Boys (69.4\%) were $\geq 2$ times at higher risk of Internet game addiction than girls (30.6\%), showing statistically significant differences in the mean. That is, as boys were remarkably more likely to become addicted to Internet games than girls, it is necessary to develop good intervention plans or preventive management [27]. This result is consistent with the research using the identical scale in elementary and middle school students [29]. The gender differences are supported by different Internet utilities, between boys mainly playing games and girls enjoying chatting [30], by longer exposure to Internet and primarily destructive and violent Internet games [29], and by different behavioral tendencies, with boys being more familiar with a computer, a kind of machine, than girls and tend to be prospective, as demanded by games [31]. It is therefore necessary to investigate the differences in resulting variables by gender and develop differentiated programs in managing the risk of Internet game addiction

Another primary factor affecting the risk of Internet game addiction for elementary school children in multicultural families is a foreign mother's continent (country) of origin. Children of foreign mothers from Southeast Asia (the Philippines, Vietnam, Thailand, and Singapore) were 2.3 times at higher risk of Internet game addiction than those from Northeast Asia (China, Japan, Mongolia, and Uzbekistan).

In the research [32], the immigrant wives giving birth before adapting themselves well to Korean culture and language became confused between the parenting style of their homeland and that of South Korea, were delayed in getting information about education, and had problems with child education. In the research [33], while children whose mother from Japan had a high level of Korean language ability and education and had relatively less difficulty in school life than those whose mother was from any other country, children whose mother was from the Philippines had difficulty in schoolwork and were teased, discriminated, and bullied.

Children whose mother was Japan were least likely to be discriminated and those whose mother was from a developing country in Southeast Asia, Central Asia, or South Asia were more likely to be discriminated. Such a difference may cause immigrant wives from Southeast Asia to become more delayed in cultural adjustment due to greater cultural alienation from South Korea and have greater difficulty in controlling children than those from Northeast Asia. This supports the finding that 
immigrant wives' country of origin may affect Internet game addiction and child education in multicultural families.

Lastly, as a factor affecting the risk of Internet game addiction, the group at risk of addiction had a 1.04 times lower level of school life adjustment. While the score for school life adjustment rarely differed with the odds ratio of 1.04 between the group at risk of Internet game addiction and the non-addiction group, the inter-group mean difference was statistically significant. This supports the finding that the lower the level of school life adjustment and the greater the difficulty with peer relationships, the higher the risk of Internet game addiction $[7,10]$.

In particular, binary logistic regression analysis was performed to determine the association among the variables affecting the risk of Internet game addiction for elementary school children in multicultural families. By doing this, it is expected to determine the association among the variables in the group at risk of addiction and the non-addiction group and provide lots of information about causal relations in general and analysis methods, contrary to the previous research using correlation and multiple regression analysis.

\section{CONCLUSION}

This is a descriptive research on the Internet game addiction risk for elementary school children in multicultural families and on the factors affecting the Internet game addiction risk. To put the results together, the factors affecting the risk of Internet game addiction for elementary school children in multicultural families were gender, foreign mother's country of origin, and school life adjustment. Beyond the finding that elementary school children in multicultural families were at higher risk of game addiction than those in general families, this study determined the level of the risk of game addiction for older elementary school children in multicultural families and identified the affecting factors. On this basis, it is necessary to share the idea about the need for preventive management of Internet game addiction and give consideration to cultural specificity in making diverse approaches to reduce exposure to the risk of Internet game addiction.

On the basis of the results, the following suggestions are made: Repetitive research should be conducted, taking other regions and environmental characteristics into account, with the aim of generalizing the results concerning the risk of Internet game addiction for elementary school children in multicultural families. It is also necessary to explore variables that can mediate or control the effects in correlation among variables that can affect the characteristics of multicultural families and the prior variables affecting the risk of Internet game addiction for elementary school children, which were not considered in this study.

\section{ORCID}

On Choi https://orcid.org/0000-0001-5159-0109

Keum Seong Jang https://orcid.org/0000-0001-5554-6105

Nam Young Kim https://orcid.org/0000-0002-8525-1604

\section{REFERENCES}

1. Kim SG. The psycho-social adaptation among children of multi-cultural families. Korean J Youth Stud 2011;18(3):247-272 (Korean).

2. Chung HS, Kim YS, Yi T, Ma KH, Park G, Tong CY, et al. An analysis on the national survey of multicultural families 2015. Seoul: Ministry of Gender Equality and Family; 2016, p. 47-68 (Korean).

3. Cheon HS, Park GS. A study on the school life of children of multicultural families. Contemp Soc Multicult 2012;2(2):415-442 (Korean).

4. Kim HH. The actual state and task of multicultural welfare for children and juveniles. Korean J Youth Stud 2007;11:75-92 (Korean).

5. Lee RH, Chang HL. The influences of closeness with parents and awareness of internet policies on internet addiction among adolescents in multicultural families in South Korea. J Digital Converg 2018;16(3): 13-25 (Korean).

6. Weinstein AM. Computer and video game addiction comparison between game users and non-game users. Am J Drug Alcohol Abuse 2010;36(5):268-276. Doi: 10.3109/00952990.2010.491879

7. Kweon YR, Park MS. Effects of school adjustment on higher grade elementary school students' Internet game addiction: focused on gender difference. J Korean Acad Psychiatr Ment Health Nurs 2012;21(2):99107 (Korean).

8. Kim KS, Kim KH. Parent related factors in Internet game addiction among elementary school students. Child Health Nurs Res 2009;15(1): 24-33 (Korean).

9. Kim MY, Lim JY, Chung GH. Effects of Korean proficiency and parentchild cohesion on self-esteem and acculturation among children from multicultural families. J Korean Acad Nurs 2012;42(6):879-888 (Korean). Doi: 10.4040/jkan.2012.42.6.879 
10. Park SM, Lee JY. Analysis of latent profiles and influencing factors on adolescents' Internet game addiction. Korean J Counsel 2018;19(6): 203-224 (Korean).

11. Cho YR, Lee HJ. A study on a model for internet addiction of adolescents. J Korean Acad Nurs 2004;34(3):541-551 (Korean).

12. Jo HI. The effect of elementary school students' perceived parenting attitude and internet use motives on internet addiction: self-control as a mediator. J Youth Welf 2011;13(4):269-287 (Korean).

13. Yoon SI, An HS, Oh SW. The influence of the attachment of parents and the stress of school life middle-school students to the Internet game addiction. J Digital Converg 2012;10(7):221-227 (Korean).

14. Ihmeideh FM, Shawareb AA. The association between internet parenting styles and children's use of the internet at home. J Res Child Educ 2014;28(4):411-425. Doi: 10.1080/02568543.2014.944723

15. Goldberg I. Electronic message posted to research discussion list 1996. Available at http://users.rider.edu/ suler/psycyber/supportgp.html [accessed on June 15, 2014].

16. Young KS. The relationship between depression and Internet addiction. Cyber Psychol Behav 1998;1(1):25-28 (Korean).

17. Hsieh FY, Bloch DA, Larsen MD. A simple method of sample size calculation for linear and logistic regression. Stat Med 1998;17(14):16231634.

18. Rosenberg M. Society and adolescent self-Image. Princeton, NJ: Princeton University Press; 1965.

19. Choi IJ. Korean parent-child relationship scale development and validation study. Seoul: National Youth Policy Institute; 2006 (Korean).

20. Woo SJ. Effects of a self-expression training program on the self-expression abilities and school adjustment of lower graders at elementary school [dissertation]. Korea National University of Education Graduate School; Korea, 2005.

21. Lim JS. Relationship with the child's dependency and school adjustment [dissertation]. Korea National University of Education Graduate School; Korea, 1993.
22. Young K. The emergence of a new clinical disorder. Cyber Psychol Behav 1996;1(3):237-244 (Korean).

23. Jung KA. Psycho-social characteristics of the computer game-addicted adolescents [dissertation]. Chonnam National University; Korea, 2001.

24. Kim MH, Kim MS. Associations among internet addiction, personality, characteristics of family system, and learned self-concept in elementary school students. Korean J Health Educ Promt 2009;26(2):63-73 (Korean).

25. Joo J. Current state of policy on teenager in multicultural family and further development. J Public Welf Adm 2011;21(2):81-99 (Korean).

26. Lee JH. Relationships among children's personality types (MMTIC), depression and school life satisfaction [dissertation]. Korea University; Korea, 2001.

27. Ozcinar Z. The relationship between internet addiction and communication, educational and physical problems of adolescents in North Cyprus. Aust J Guid Counsell 2011;21(1):22-32.

28. Brucw G, Simon-Morton, Crump AD. Association of parental involvement and social competence with school adjustment and engagement among sixth graders. J Sch Health 2003;73(3):121-126.

29. Park HS, Kwon YH, Park K. Factors on Internet game addiction among adolescents. J Korean Acad Nurs 2007;37(5):754-761 (Korean).

30. Oh WO. Computer game addiction and it's predictors of Korean elementary school children. J Korean Acad Nurs 2004;10(3):282-290 (Korean).

31. Kuss DJ, Griffiths MD. Internet gaming addiction: a systematic review of empirical research. Int J Ment Health Addict 2011;10(2):278-296.

32. Yang JH, Park HJ, Kim SS, Kang EJ, Byun SH, Bang JS. Adaptation experience to family of immigrant women in multicultural families. J Korean Acad Nurs 2012;42(1):36-47 (Korean).

33. Jun KS, Song MK. A research on the differences of adjustment level by multicultural children's nationality. Korean J Youth Stud 2011;18(11): 305-330 (Korean). 


\section{국문초록}

\section{다문화가정 초등학생의 인터넷 게임중독위험에 영향을 미치는 요인}

\section{최 온'장금성'김ㅁ남영}

1전남대학교 간호대학 박사과정, ${ }^{2}$ 전남대학교 간호대학 교수, ${ }^{3}$ 호남대학교 간호대학 교수

목적: 본 연구는 다문화가정 초등학생의 인터넷 게임 중독위험군과 비중독군 간의 자아존중감, 부모-자녀 관계 및 학교생활적응 정도 에 차이가 있는지 확인하고, 인터넷 게임중독위험에 영향을 미치는 요인을 파악하기 위해 시도되었다.

방법: 본 연구에서는 광주광역시와 전라남도 지역에서 편의 표집된 다문화가정 초등학교 4-6학년 209명의 자료가 분석되었으며, 연구 자료는 자가 보고식 질문지로 2013년 1월 24일에서 4월 17일까지 수집되었다. 수집된 자료의 분석은 IBM SPSS 21.0 program을 이용하여, 서술적 통계, t-test, $\chi^{2}$-test, Fisher's exact test, 이원로지스틱 회귀분석(Binary logistic regression analysis)을 실시하였다.

결과: 본 연구결과 다문화가정 초등학생의 인터넷 게임 비중독군과 중독위험군 간의 자아존중감, 부모-자녀관계와 학교생활적응은 통 계적으로 유의한 차이를 보였다. 또한 다문화가정 초등학생의 인터넷 게임중독위험에 영향을 미치는 요인은 성별, 외국 어머니의 출신 국가, 학교생활 적응 순으로 나타났다.

결론: 이상의 결과를 바탕으로, 다문화가정 초등학생을 대상으로 한 인터넷 게임중독정도에 대한 광범위한 실태파악이 우선적으로 실 시될 필요가 있으며, 인터넷 게임중독위험 예방프로그램을 개발하는 데 있어 문화적 특수성을 고려할 필요가 있다.

주제어: 인터넷 게임, 중독, 자아존중감, 부모-자녀 관계, 학교생활적응 